\title{
Archaeology of the Contemporary Past vs Retrotopia in the Context of the Application of Remote Sensing Methods
}

\section{Introduction}

I discovered the possibility of using Zygmunt Bauman's concept of retrotopia (2018) thanks to a fragment of the introduction to his last book, in which he points out that the boundaries between the past and the future are blurred in the present day. This statement is very close to the issues considered in the work of V. Buchli and L. Gavin (2002) Archaeologies of the Contemporary Past. As a person agreeing with such an approach, I started perceiving the phenomenon of retrotopia as an issue that perhaps should also be dealt with by archaeologists. Retrotopia is a concept proposed by sociologist Zygmunt Bauman. It refers to the contemporary society that persistently sticks to the past and idealises it. Bauman draws particular attention to the significance of the past in the shaping of the present. Referring to historical relativism, he states that we do not have full knowledge of the past, and the gaps in it are used to create interpretations meeting the demand of the authorities. Thus, idealisation of the past leads to the recycling of old ideas and methods as 'ideal' solutions to contemporary problems, even though they failed before (Bauman 20I8: 6).

Archaeologists as people who study the past are particularly responsible for creating the knowledge of the past, which is why they can respond to any emerging gaps in the knowledge of the past and make efforts to provide these areas with more data. Over the last years, one of such gaps filled in by archaeologists is knowledge of the contemporary past, which, combined with the emergence of new possibilities of conducting archaeological surveys, can offer new information about the twentieth-century heritage. Remote sensing methods, 
and particularly airborne laser scanning, can be used to conduct research into the contemporary past as 'objective' tools that, if used properly, do not take into consideration such factors as ethnicity or ethnic conflicts. Thus, at least theoretically, their application should not be burdened with idealisation of the past or its selective use. The provided information about the landscape covers all its elements and not only the ones we would like to include.

The aim of my paper is to answer the following question: Can the application of remote sensing methods within the archaeology of the contemporary past have an effect with regard to the concept of retrotopia and what the effect would be? I would like to answer this question based on a case study of research into the transformation of the cultural landscape near Chojnice and Człuchów in the $20^{\text {th }}$ century. I will analyse transformations connected with the end of the Second World War. The area near Człuchów, which at the time (until 1945) was located in Germany, was incorporated into Poland. As a result, a large group of inhabitants was resettled, while new settlers arrived. In consequence, about seventy homesteads and ten Evangelical cemeteries were abandoned: after 1945 they disappeared from the public space and entered the archaeological context. In this paper, I analyse one of such abandoned settlements - Witkowski Młyn.

\section{Retrotopia as a Concept of Mythologisation of the Past?}

The term 'retrotopia' is a combination of the words 'retro' and 'utopia'. Bauman explains this concept using the painting Angelus Novus by Paul Klee. It was first interpreted by Walter Benjamin as the Angel of History as follows:

\footnotetext{
His face is turned toward the past. Where we perceive a chain of events, he sees one single catastrophe which keeps piling wreckage upon wreckage and hurls it in front of his feet. The angel would like to stay, awaken the dead, and make whole what has been smashed. But a storm is blowing from Paradise; it has got caught in his wings with such violence that the angel can no longer close them. The storm irresistibly propels him into the future to which his back is turned, while the pile of debris before him grows skyward. This storm is what we call progress (Benjamin 20I2: 316).
}

Nearly a century later, Bauman (2018: 8) proposed a completely different interpretation of the painting:

[...] His face is turning from the past to the future, his wings being pushed backwards by the storm blowing this time from the imagined, anticipated and feared-in-advance hell of 
the future towards the paradise of the past. It has got caught in his wings with such violence that the angel can no longer close them.

The basis for Bauman's concept of retrotopia includes two main phenomena: functioning within a global epidemic of Nostalgia defined by Svetlana Boym (200I) as "[...] an affective yearning for a community with a collective memory, a longing for continuity in a fragmented world", which is "[...] a defence mechanism in a time of accelerated rhythms of life and historical upheavals". This concept gives rise to the first part of retrotopia - "retro", meaning references to the past. The second part 'topia' means that it is a successor to the term 'utopia' proposed by Thomas More. More precisely, retrotopia comes from the double negation of utopia as proposed by More, meaning its rejection and then resurrection. Retrotopia refers to "[...] visions located in the lost/stolen/ abandoned but undead past, instead of being tied to the not-yet-born and so inexistent future" (Bauman 2018: 5). According to Bauman, retrotopia consists of four main returns:

back to Hobbes;

back to tribes;

back to inequality;

back to the womb.

Each of them is made up of smaller components. Referring to them all would require an extensive study, which is why in the following part of this paper I will only refer to the one that is most connected with archaeology, meaning the phenomenon described as 'return back to tribes' (Bauman 2018: 88). It invokes the classical anthropological distinction 'we vs them' based on references to the ancestral heritage. Bauman once again cites the work by Lowenthal (1997), which states that faced with the fading hopes related to the development and the future, heritage offers us comfort in the form of tradition. Such tradition provides us with scraps of stability in today's rushing and changing world. Thus, we start to perceive heritage in the way that suits us, even if we do not know much about it. In his work, Lowenthal (1997: 134-135) notes that 'the past is more admirable as a realm of faith than of fact'.

\section{Dichotomy: Realm of Faith vs Realm of Fact}

Lowenthal (1997: 134) understands the realm of faith as heritage based on ambiguous and vague lore, as exemplified by the founding fathers Romulus and Remus or King Arthur. They are unspecified characters, the stories of whom are full of insinuations and leave recipients a lot of room for interpretation. On 
the other hand the realm of fact is presented as history, which also talks about founding fathers, such as Jefferson (Lowenthal 1997: 135). However, we know so many details of his life and activity that it becomes very realistic, leaving very little room for interpretation.

Thus, the realm of faith presents vague, mythical and oblique past. According to Lowenthal, this intriguing, enigmatic nature of heritage is much more interesting than dry facts (Lowenthal 1997: 136). As he explains in the summary, which Bauman also draws attention to, the reason for this is that "[...] myopic rivalry is [...] endemic to the very nature of heritage. To insist we were the first or the best, to celebrate what is ours and exclude others, is what heritage is all about" (Lowenthal 1997: 239).

\section{Dichotomy: Polish National Narrative vs German Heritage}

There is a similar dichotomy with regard to the twentieth-century German heritage in question, with the realm of faith represented by the contemporary society's idea about it. It is very limited, as proven by the work Niematerialne dziedzictwo kulturowe Pomorza Wschodniego (ed. Kwaśniewska 20I7) ${ }^{\mathrm{I}}$, which provides ethnographic interviews with no elements of German heritage appearing for the area discussed in this paper and including the Communes of Chojnice, Człuchów and Debrzno (Klein-Wrońska, Kwaśniewska 2017: I50I52; Kwaśniewska 20I7: 239-242). However, the researchers draw attention to the attitude of the society towards such heritage based on the way cemeteries are treated in Eastern Pomerania (Kwaśniewska 2016). To Kwaśniewska, the abandoning and devastation of Evangelical cemeteries constituting traces of Germans who used to live in the area prove that remembrance of the previous inhabitants is marginalised. This is a very good example of a situation in which people create their own heritage in opposition to 'the Others'. The Others in the area in question were Germans. The process of building local identity, which is completely new and different, was based on erasing the presence of former inhabitants, which corresponds to the attitude towards heritage described by Lowenthal as 'myopic rivalry'. This could happen thanks to gaps in the knowledge of the region's history.

Within the scientific narrative, the twentieth-century history of the region is only occasionally present in the comprehensive study of the region's history (cf. Dzieje Sępólna Krajeńskiego... 2010). No one devoted any scientific study to

I Even though the subject of the research was non-material cultural heritage, its aim was also to document material elements, such as cemeteries (Niematerialne dziedzictwo kulturowe Pomorza Wschodniego...: 20). 
the issue of the transformation of settlement after 1945, meaning the issue of the German heritage in the given area. There are some isolated grassroots attempts to revive the memory of its previous inhabitants ${ }^{2}$, however, their effect on the society's knowledge is limited. Thus, one could say that, in the face of scarce historical studies, the narrative concerning this issue in the area in question is dominated by the realm of faith. Incomplete knowledge of the region's history before 1945 and the fact how easy it was to erase it when Germans left pushed the multi-national past of the area into the background.

The emergence of the ALS data in Poland and popularisation of its use have introduced into the archaeological discourse a new type of relics, i.e. remains of homesteads of the twentieth-century German heritage (cf. Zapłata, Ptak 20I5; Duma, Łuczak, Piekalski 20I7; Majewska 20I7; Banaszek 2019). Objects of this type can be very easily captured using this method as they still have their own landscape form in forested land. A significant role is also played by the fact that forested land was very difficult to explore using traditional methods of archaeological survey, such as surface survey. Only the last few years and popularisation of ALS brought about an influx of new information about archaeological heritage in forested land. This is why I believe that using this method can play an important role with regard to the phenomenon of retrotopia by providing new information and filling in a certain gap in knowledge of the twentieth-century German heritage.

\section{Witkowski Młyn - A Case Study}

Until the I940s, Witkowski Młyn was a small settlement located on the Kamionka River. Its whole existence was based on a mill. Witkowski Młyn was 'brought back to life' only in the $2 \mathrm{I}^{\text {st }}$ century, when a new house was built near the remains of the mill. We know very little about the history of the village. It is an out-of-the-way place which has never been studied. It is only mentioned in Dzieje Sępólna Krajeńskiego... (2010), chapter IX Szkice z dziejów wsi podsepolenskich, and the last few decades of its existence are described on the information board at the remains of the mill.

During the research conducted, I adopted the following methodology:

1. I identified abandoned homesteads based on historical and contemporary cartographic sources;

2 This can be exemplified by the plaque in Witkowski Młyn, founded by the local organisation Mtodzieżowa Grupa Śladowców in order to commemorate the settlement existing there before 1945. It includes photographs of the mill described from the time of its operation as well as brief information about its history. 
2. For the abandoned homesteads identified, I analysed the results of airborne laser scanning in order to determine whether their material relics have been preserved in a given place. For the analysis, I used the measurement data in the *.las format. Based on it, I generated a DEM, which I used to create a number of visualisations. Then I analysed the visualisations and provisionally identified relics of homesteads;

3. I conducted verification field research in Witkowski Młyn with the aim to document in detail the preserved relics of homesteads and other elements of the twentieth-century cultural landscape that cannot be captured in the ALS data. When analysing the historical cartographic sources, I determined that Witkowski Młyn, during its existence in the $20^{\text {th }}$ century, consisted of thirteen buildings, four of which have preserved its landscape form visible in the ALS results (Fig. I no. 2, 3, 4, 7). The following step was to perform field verification and detailed measurements of selected buildings, during which it turned out that seven of the buildings have not been preserved (Fig. I A-G). However, I discovered relics of two buildings (Fig. I no. I and 8), which can be seen in the results of airborne laser scanning as irregular hollows. This is why they were not identified as relics of buildings during the first interpretation of the ALS results. During the field verification, I documented two relics of buildings that cannot be seen in the ALS data (Fig. I no. 5 and 6) because of the dense vegetation that impaired the data quality. The way two buildings (Fig. I no. 3 and 7) look on visualisations differs from their actual state of preservation. Due to the original classification of point clouds, the NE wall of building 7 and the SE wall of building 3 were removed from the relic visualisation. Nearly all relics of buildings have been preserved in the same form: as remains of foundations. Their brick parts were pulled down after the war ${ }^{3}$.

During the field research, I also documented two other elements of the cultural landscape from the first half of the $2 \mathrm{O}^{\text {th }}$ century. The first includes fruit trees being relics of an orchard marked on a topographic map from 1935. Eleven trees have been preserved (nine apple trees and two pear trees). Some of the trees were cut down, but you can still see their stumps. The other element of the documented landscape includes remains of a cemetery, which was also marked on the topographic map from 1935. However, it is not a typical Evangelical cemetery as it has gravestones made of rocks (I documented ten of them). Similar cemeteries can still be found today in Germany, but with inscriptions on rocks made of metal letters. The rocks in the cemetery in Witkowy Młyn have no preserved letters. The cemetery has flora typical of such places.

3 Oral information from a present inhabitant of Witkowski Młyn. 


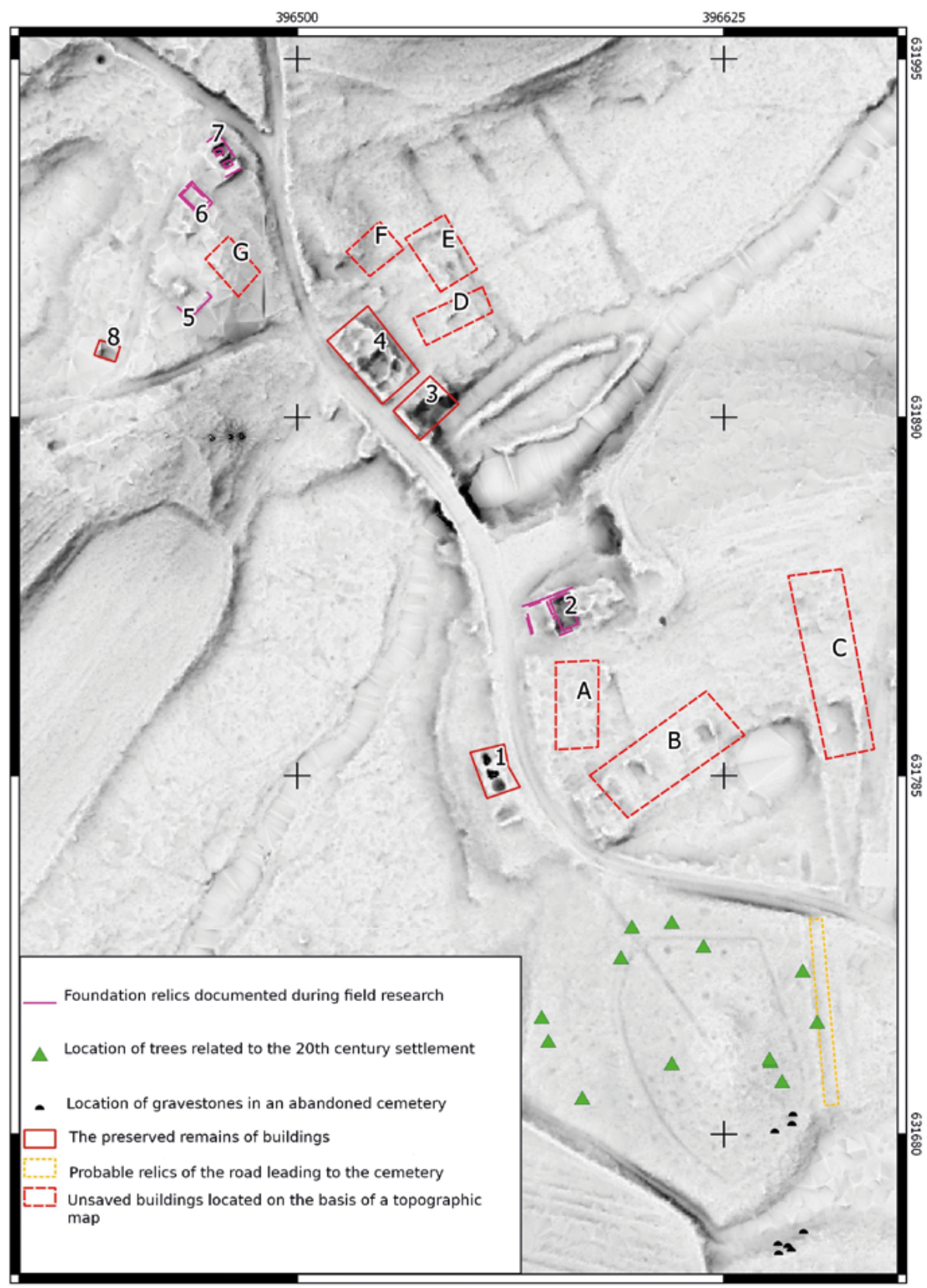

Fig. 1. Remains of the twentieth-century landscape of Witkowski Młyn. Background - sky view factor visualisation (prepared by Filip Wałdoch). 
During the field research, I also identified two chestnut trees (Fig. I, two trees growing at the remains of a road), which were planted within this landscape by people (more about flora in abandoned homesteads: Wojciechowska 2008). They grow near a small depression, which may be what remained of a road leading to the cemetery.

The case study presented well exemplifies the challenges faced by the application and interpretation of ALS data in the context of research into the contemporary past. First of all, this method does not work very well in places with dense vegetation, which is proven by buildings 5 and 6 , the remains of which cannot be seen in visualisations based on the ALS data (Fig. 2).

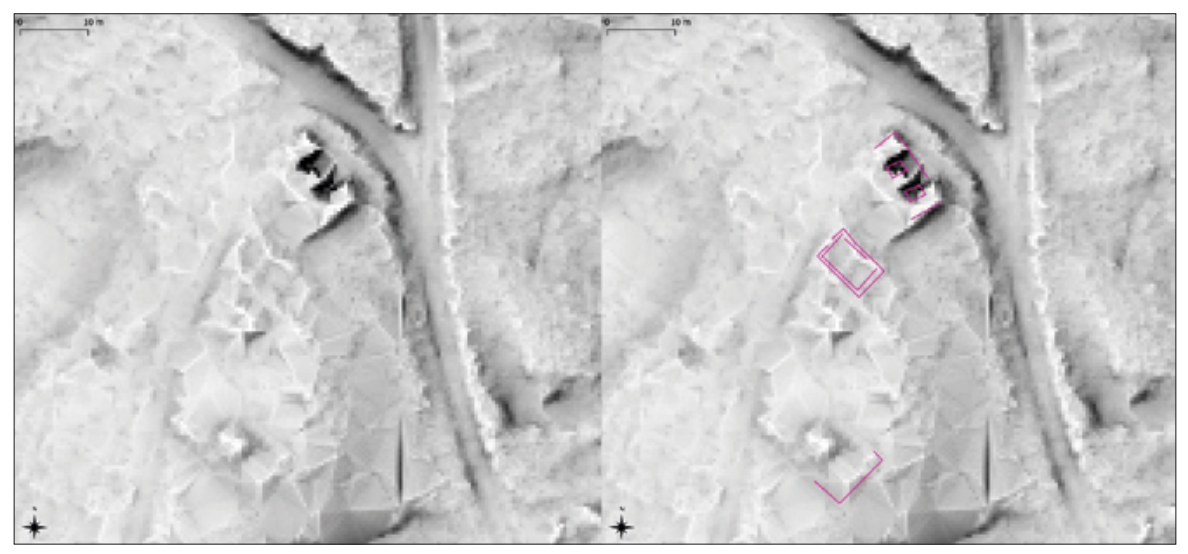

Fig. 2. Examples of relics of buildings (purple line - relics documented during field research) that cannot be seen in visualisations based on the ALS data. The visualisation used - sky view factor (prepared by Filip Wałdoch).

Another challenge presented to the use of such data is lack of the possibility of capturing small (e.g. gravestones) and atypical (trees ${ }^{4}$ ) objects, which are important elements of the landscape of Witkowski Młyn from the first half of the $20^{\text {th }}$ century. The case study presented shows that in order to fully use the potential of this method it is necessary to combine it with other data sources.

What gaps in knowledge about the recent past are completed by the presented case study? An analysis of cartographic sources shows the disappearance

4 ALS data is successfully used by foresters for the identification of tree species. I made a similar attempt in this case (I presented it as a poster "Possibility of Tree Identification Connected with Households from the $19^{\text {th }} / 20^{\text {th }}$ Century Based on Remote Sensing Data" at the Aerial Archaeology Research Group conference in 2017). Insufficient resolution of the data combined with irregular shapes of tree crowns made it impossible to explicitly identify fruit trees. 
of the Witkowski Młyn settlement after 1945. Objects existing on the pre-war topographic map, such as a cemetery, orchard or buildings do not appear on post-war maps. Based on these sources, it would seem that there has been a complete transformation of the landscape. The buildings were removed and a forest appeared in their place. However, the use of ALS, complemented by field studies, shows the complexity of the process. Of the thirteen buildings identified on the pre-war map, relics of six of them are still visible in the landscape. Two more not included on the map were documented during field research. Thus, the objects from the pre-war map still exist, although in a very limited form of foundations. Just as relics of buildings have survived, so has preserved part of the orchard or cemetery, which are also included in modern maps. They lost their original role. The orchard passed into the hands of the forest inspectorate and its task ceased to be supplying apples. The cemetery ceased to serve as a place to bury the dead.

So the map as a certain schematic reflection of reality does not reflect all the processes taking place in the landscape. This physical gap is to some extent supplemented by ALS, which documents the topography of the terrain in a very detailed way, in which relics of buildings are still visible in varying degrees of preservation. Moreover, detailed field measurements show that these objects are preserved much better than it might seem after the initial analysis of ALS derivatives. Of course, this is not an ideal method (as shown in Figure 2) and must be used in a conscious way.

I believe that the application of remote sensing methods can fill not only physical gaps but also metaphorical ones. This twentieth-century German heritage thanks to ALS acquires a more material dimension. The abandoned settlement of Witkowski Młyn gains a new face. Based on which new history of this microregion should be created. In which German farms, buildings, orchards and cemeteries do not disappear from the landscape with their original users. On the contrary, they persist in the landscape, reminding of the $2 \mathrm{O}^{\text {th }}$-century multicultural fate of these areas. Basing the narrative on these material relics can increase awareness of this type of heritage. Thus, by filling the gap in the memory of society which is indicated by the ethnographic research presented earlier.

\section{Conclusions}

Even though ALS is not a perfect method, it contributes much to the knowledge of the contemporary past. It may not offer us much new information about the appearance of Witkowski Młyn in the first half of the $20^{\text {th }}$ century, 
however, it allows to document its present condition. Combined with other information, it shows how many of its elements have survived until today. Such use of remote sensing data can thus contribute to an increase in the awareness of the twentieth-century German heritage.

It is also a fully inclusive method, which I understand as documenting all elements of the landscape, without being limited to objects related to a specific nation or culture. Of course, there are some limitations that I presented in this paper. It is influenced by the researcher who decides how to use it. It is not an objective method. The very fact of registering material relics of the contemporary past is only a prelude to a dialogue about the unquestionably difficult heritage discussed in this paper. Such a dialogue, as Z. Bauman notes in the summary of his work, can weaken retrotopia, which cannot be completely avoided.

Thus, remote sensing methods will never prevent retrotopia but they are new tools allowing to fill in some gaps in the knowledge of the contemporary past.

\section{Bibliography}

Banaszek Ł. (2019), The Past amidst the Woods. The Post-Medieval Landscape of Polanów, Ad rem, Poznań.

Bauman Z. (2018), Retrotopia. Jak rządzi nami przesztość, Wydawnictwo Naukowe PWN, Warszawa.

Benjamin W. (2012), Konstelacje. Wybór tekstów, trans. A. Lipszyc, A. Wołkowicz, introd. A. Lipszysc, Wydawncitwo Uniwersytetu Jagiellońskiego, Kraków.

Boym S. (2001), The Future of Nostalgia, Basic Books, New York.

Buchli V., Gavin L. (2002), Archaeologies of the Contemporary Past, Routledge, New York, https://doi.org/10.4324/9780203185100

Duma P., Łuczak A., Piekalski J. (2017), Badania nad nowożytnym osadnictwem wiejskim w miejscowości Kopaniec w Górach Izerskich, "Ochrona Zabytków”, 2, p. 175-187.

Dzieje Sępólna Krajeńskiego (2010), Z. Biegański (ed.), Biblioteka Publiczna im. Jarosława Iwaszkiewicza w Sępólnie Krajeńskim, Sępólno Krajeńskie.

Klein-Wrońska S., Kwaśniewska A. (2017), Niematerialne dziedzictwo kulturowe w powiecie chojnickim, [in:] A. Kwaśniewska (ed.), Niematerialne dziedzictwo kulturowe Pomorza Wschodniego. Katalog, vol. I, Uniwersytet Gdański, Gdańsk, p. 149-234.

Kwaśniewska A. (2016), Niematerialne dziedzictwo kulturowe na terenach postmigracyjnych (na przyktadzie Pomorza), "Eódzkie Studia Etnograficzne”, 55 (1), p. 46-79, https://doi.org/10.12775/LSE.2016.55.04 
Kwaśniewska A. (2017), Niematerialne dziedzictwo w powiecie cztuchowskim, [in:] A. Kwaśniewska (ed.), Niematerialne dziedzictwo kulturowe Pomorza Wschodniego. Katalog, vol. I, Uniwersytet Gdański, Gdańsk, p. 235-302.

Lowenthal D. (1997), The Heritage Crusade and the Spoils of History, Viking, New York, https://doi.org/10.1017/CBO9780511523809

Majewska A. (2017), Relikty zaniktych jednostek osadniczych na pograniczu mazursko-mazowieckim. Interdyscyplinarny projekt badawczy, "Acta Universitatis Lodziensis. Folia Archaeologica", 32, p. 215-235, https://doi. org/10.18778/0208-6034.32.09

Niematerialne dziedzictwo kulturowe Pomorza Wschodniego. Katalog, vol. I (2017), A. Kwaśniewska (ed.), Uniwersytet Gdański, Gdańsk.

Wojciechowska M., (2008), Flora dawnych gospodarstw w Parku Narodowym 'Ujście Warty' i jego okolicy, "Parki Narodowe i Rezerwaty Przyrody”, 27 (2), p. 19-29. Zapłata R., Ptak A. (2015), Dziedzictwo kulturowe w świetle danych ALS. Zasoby ISOK w badaniach rejonu Bobolic: metodyka, analiza i wyniki, [in:] M. Pawleta, R. Zapłata (ed.), Nieinwazyjne rozpoznanie zasobów dziedzictwa archeologicznego. Potencjat i możliwości, E-Naukowiec; Fundacja “5Medium”, Lublin, p. 99-140.

\section{Summary}

\section{Archaeology of the Contemporary Past vs Retrotopia in the Context of the Application of Remote Sensing Methods}

This paper considers the issue of the application of teledection methods in the archaeology of the contemporary past with reference to the concept of retrotopia proposed by Zygmunt Bauman. It is based on one of the components of retrotopia, namely the approach to heritage adopted by Lowenthal (1997). From this perspective, relics of the twentieth-century German settlement in Witkowski Młyn (Western Pomerania) are analysed. In order to identify and document them, ALS data was used and then supplemented with verification field research. As a result, extensive relics of the twentieth-century landscape were documented, including relics of homesteads, orchards and a cemetery. The research presented show that teledection methods cannot prevent retrotopia, but they are new tools for filling in the gaps in knowledge of the contemporary past. Thus, they can lead to a dialogue which, according to $\mathrm{Z}$. Bauman, is the best response to retrotopia.

Keywords: archaeology of the contemporary past, landscape archaeology, remote sensing, retrotopia, airborne laser scanning 


\section{Streszczenie}

Archeologia współczesności vs retrotopia w kontekście aplikacji metod teledetekcyjnych

Artykuł rozważa kwestię wpływu wykorzystania metod teledetekcyjnych w archeologii współczesności w odniesieniu do koncepcji retrotopii zaproponowanej przez Zygmunta Baumana. Praca opiera się na jednej z części składowych retrotopii, a mianowicie podejściu do dziedzictwa prezentowanego przez Lowenthal'a (1997). Przez jej pryzmat przeanalizowane są relikty XX-wiecznego niemieckiego osadnictwa na Pomorzu Wschodnim w Witkowskim Młynie. Do ich rozpoznania i zadokumentowania zostały wykorzystane dane z lotniczego skanowania laserowego, uzupełnione weryfikacyjnymi badaniami terenowymi. Ich efektem jest zadokumentowanie kompleksowych reliktów XX-wiecznego krajobrazu składającego się z reliktów gospodarstw, sadów czy cmentarza. Przedstawione badania pokazują, że metody teledetekcyjne nie zapobiegną retrotopii, ale są nowym narzędziem uzupełniającym luki w wiedzy o nieodległej przeszłości. Tym samym prowokując dialog, który jest zdaniem Z. Baumana najlepszą odpowiedzią na retrotopię.

Słowa kluczowe: archeologia współczesności, archeologia krajobrazu, teledetekcja, retrotopia, lotnicze skanowanie laserowe

Filip Wałdoch, PhD student

Adam Mickiewicz University in Poznań, Faculty of Archaeology

e-mail: filwal@amu.edu.pl 